\title{
A DEFENSE OF THE MCCARRAN-WALTER ACT
}

\author{
ROBERT C. AlEXANDER*
}

INTRODUCTION

There are two fundamental principles of basic policy from which to choose in controlling immigration into any country. The first is that every alien shall be admitted unless there is some law or other authority which, in an individual case, requires that he be excluded. The second is that no alien shall be admitted unless there is some law or other authority which permits such entry. As these two basic concepts are almost diametrically opposed, it follows that a nation may adopt either, but not both, in determining its immigration policy and formulating its system of control.

The United States has always followed the first principle, while most of the other countries of the world have predicated their control of immigration on the second. This, of course, does not mean that aliens have an inherent or abstract legal right to enter the the United States, as immigration into any country is only a privilege. But, once an alien is found by our administrative authorities to be without disqualification for admission, a definite legal right to enter is acquired, and he can not be excluded by whim or caprice. Thus, under the due process clause in the fifth amendment to the Constitution, our courts are available, through the writ of habeas corpus, to aliens who are detained at a port of entry; foreign countries, on the other hand, generally deny such access to their courts, there being no analogous legal right to be adjudicated.

The immigration laws of the United States were enacted by Congress over a period of many years without any appreciable over-all planning, particularly concerning the ethnic composition of our population. In fact, it may be said that our immigration laws "just grew," like Topsy or the streets of Boston. Our early history shows that we welcomed all immigrants from all sources. Only in later years were restrictions-first, qualitative in nature, and finally, quantitative in limitation and procedural in character-imposed upon immigration. The sum-total of all restrictions to date, however, has not changed the fundamental policy of the United States, which still permits any alien to come to this country from any part of the world at any time, unless some provision of our law, in his individual case, precludes migration. If the restriction is qualitative, it may bar the alien indefinitely; but if it is merely quantitative or procedural, it will only delay his migration.

* Formerly Technical Adviser and Assistant Director, Visa Office, Department of State, 1938-53; Technical Adviser, United States Delegation, American-British Refugee Conference, Bermuda, 1943; Assistant Administrator for the Refugee Relief Program, Bureau of Security, Consular Affairs, and Personnel, Department of State, 1953-54. 
Our immigration laws today are incorporated, with very few exceptions, in the Immigration and Nationality Act, ${ }^{1}$ which is also known as the McCarran-Walter Act because it was introduced in the Senate ${ }^{2}$ by the late Senator Pat McCarran, of Nevada, and in the House of Representatives ${ }^{3}$ by Congressman Francis Walter, of Pennsylvania. This statute was not hastily drawn. Nearly five years ${ }^{4}$ of comprehensive study ${ }^{5}$ and painstaking drafting were required to produce it. Public hearings were held on the early drafts of the bills while the legislation was pending in Congress, and the bills were redrafted and reintroduced several times ${ }^{6}$ before Congress enacted H. R. 5678, Congressman Walter's second draft bill, with amendments agreeable to the Senate and the House of Representatives. ${ }^{7}$ President Truman returned the bill to the House of Representatives on June 25 , I952 with a veto message; ${ }^{8}$ but on June 26,1952 , the House of Representatives voted, 278 to $\mathrm{II}_{3}$, to sustain the bill, which became a law on June 27, I952, when the Senate voted, 57 to 26, to override the veto. ${ }^{2}$ The act became fully effective on December $24,1952$.

The act is primarily a compilation and codification of our previous laws on immigration, deportation, nationality, and naturalization, and is only secondarily a very limited revision of these laws. Some of its severest critics privately concede that it is a vast improvement over the old laws because of its codification features alone, and they concur in many of its revisionary clauses. Their principal objection to it seems only to be that it does not go quite as far as they would wish in substantively revising some of the old laws. Nevertheless, these critics are notably silent today regarding the act's admittedly desirable features, preferring to concentrate their attention and attacks on the few provisions that they consider unsatisfactory. This may tend to create in the public mind the erroneous impression that they are opposed to the entire act; but the fact is that they have incorporated many of its improvements and prescient provisions in the multitude of "dream" bills, many of them identical, with which they have flooded Congress. ${ }^{10}$ A defense of the act, accordingly, does not require a comprehensive and exhaustive review of its numerous provisions, many of which are acceptable to even its most uncompromising critics. Instead, a discussion of the few provisions under attack and the merit, or lack of it, in the complaints would appear to be sufficient.

266 Stat. 163, 8 U. S. C. $\$ \$$ II0I-503 (1952). ${ }^{2}$ S. 3455 , 8xst Cong., 2d Sess. (1950).

${ }^{3}$ H. R. 2379, 82 d Cong., Ist Sess. (1951).

'S. Res. 137, 80th Cong., Ist Sess. (1947), authorized the study of the immigration and naturalization laws which culminated in the enactment of the McCarran-Walter Act on June 27, 1952. See 93 Cong. Rec. 7879, 8656, 8993, 9807, ror6o, 10324, 10348, 10352 (1947).

${ }^{8}$ See S. Rep. No. 1515, 81st Cong., Ist Sess. (1951).

'S. 7I6, S. 2055, H. R. 5678, 82 d Cong., Ist Sess. (I95I); S. 2550, 82d Cong., 2d Sess. (I952).

${ }^{7}$ See H. Rep. No. 2096, 82d Cong., 2 d Sess. (1952).

${ }^{8}$ H. Doc. No. 520, 82d Cong., 2d Sess. (1952).

98 Cong. Rec. 8214,8253 (I952).

${ }^{10}$ E.g., H. R. 2916, 82d Cong., xst Sess. (195I); S. 2842, H. R. 7032, 82d Cong., 2d Sess. (1952); S. 3292, H. R. 8802 , H. R. 8807,83 d Cong., 2d Sess. (1954); S. 1206, H. R. 58, H. R. 474, H. R. 512, H. R. 516, H. R. 636, H. R. 684, H. R. 1578, H. R. 1613, H. R. 4430, H. R. 4431, H. R. 4432, H. R. 4433 , H. R. 4434 , H. R. 4477 , H. R. 4535, H. R. 4625 , H. R. 4797 , H. R. 4805, H. R. 5434 H. R. 5514 , H. R. $6058,84^{\text {th }}$ Cong., ist Sess. (1955). 
II

\section{National-Origins Quota System}

Most of the criticism of the McCarran-Walter Act seems to be directed at the national-origins system it employs for the allocation of annual immigration quotas. ${ }^{11}$ A myth has been propagated by some critics that this system is based upon a superrace theory and that it was intended to discriminate against peoples who were considered to be racially or otherwise inferior-more specifically, the southern European, southeastern European, and Asian countries, to which only small quotas have been allocated. If, however, the fact that some countries have smaller quotas than others constitutes discrimination, then any quota system would be discriminatory, unless all countries were allocated equal quotas-an expedient that no one has yet advocated.

\section{Determination of the Quotas}

The national-origins quota system was originally authorized in the Act of May $26,1924 .{ }^{12}$ It was perpetuated with only a slight revision in the new act, having established its basic merit through its many years of operation. Under the system as originally enacted, the quota countries of the world were allocated portions of a theoretical annual world quota of 150,000 , subject to a minimum-quota limitation of 100, below which the quota of no country could fall. This minimum-quota provision raised the actual total of the world's quotas to approximately 154,000. Each quota country, therefore, received a minimum quota of Ioo or a larger portion of the theoretical world quota in precise proportion to its contribution of immigrants and their descendants to the United States, as computed under the census of rg20, which was the last decennial census available to Congress at the time. Thus, for example, if the computation had shown that Germany had contributed one-sixth of the total of all people in our foreign national-origins groups, Germany would have been entitled to an annual quota of one-sixth of the theoretical world quota of 150,000, or a quota of 25,000 annually.

The McCarran-Walter Act made a minor, but perhaps significant, change in the method of computing quotas. It abandoned the theoretical world quota and substituted a uniform ratio of one-sixth of one per cent of the number of people in each of our foreign national-origins groups as the new mathematical basis for computing each national-origins quota. ${ }^{13}$ This has resulted in a slight reduction of some quotas, but the addition of several new quotas for the Asian peoples, whom the McCarranWalter Act made eligible, for the first time, for quota immigration and naturalization in the United States, has brought the total of the world's quotas back to approximately 154,000 .

The significance of this change is two-fold. Of immediate importance th the

11 All countries of the world are quota countries, except the independent countries of the vestcrn hemisphere, Canada, and the Canal Zone, which are nonquota countries. 66 STAT. I69, 8 U. S. C. $\$ \operatorname{IrOI}(a)(27)(c)(1952)$.

12 Act of May 26, 1924, c. 190, $\$ 11,43$ STAT. 153.

${ }^{13} 66$ STAT. I75, 8 U. S. C. $\$$ II5I(a) (1952). 
time, it tended to provide space within the existing total of the world's quotas for the new quotas for Asians; but of more long-range importance, it permitted ready readjustment should a new census be substituted for that of 1920 in the formula for the computation of national-origins quotas. Thus, if Congress should decide to increase the annual volume of permissible quota immigration, it may do so either by employing a census later than that of 1920 , or by retaining that earlier census and merely changing the uniform ratios from one-sixth of one per cent to some other percentage figure. In other words, the census is no longer necessarily the critical element in the quota formula.

For example, it is estimated that if the Ig20 census should be replaced by that of 1950, without changing the uniform ratio, the total of the new annual quotas for the world might reach 25x,000, an increase of approximately forty per cent. However, a similar result could be more readily attained, without undertaking the tremendous and years-consuming task of redetermining the number of people in each of our foreign national-origins groups, by retaining the census of 1920 and merely changing the uniform ratio from one-sixth to one-fifth, or one-fourth of one per cent, or some other percentage figure. In any event, the change effected by the McCarranWalter Act in the method of quota computation means that Congress has figuratively tucked into its collective bosom another key to the quota chest and may now readjust or revise all quotas merely by changing one word in the law-the census year, or the uniform ratio, or both.

\section{Policy of National-Origins System}

The national-origins quota system is like a mirror held up before the American people. As our various foreign origins are determined upon a basis of nationality and reflected in the mirror, the quotas of the countries of our origin are proportioned. The basic policy of the system is to grant to each group its fair shareno more and no less-of the permissible volume of annual quota immigration. Any other distribution of the quotas would, indeed, be discriminatory. One who objects to such an equitable distribution of immigration quotas must object to the ethnic composition of our population and must wish to alter it in favor of some particular group or groups. Thus, for example, in demanding a proportionately larger quota for Italy, one would be advocating that we become proportionately more Italian than we are. Italians would quite naturally favor this, but do the people in all of our other national-origins groups, which constitute the majority, also favor it? Without necessarily entertaining the slightest disregard or lack of friendship and admiration for the Italian people, the majority would naturally favor immigrants of their own national origins.

In a democracy like the United States, the majority prevails, without oppression of minorities. Those who believe in minority rule, or in the tail-wagging-the-dog policies of such a system, must have little faith in our institutions or in our American way of life. Perhaps this explains one of the reasons why the Communist Party 
in the United States has organized a drive to arouse opposition to the McCarranWalter Act. In a recent article, ${ }^{14}$ Mr. J. B. Matthews, a recognized authority on Communist subversive activity, refers to the questioning of a witness by the Senate Subcommittee on Internal Security, on June 23, 1954, regarding the Communist origin of the now-exposed National Committee to Repeal the McCarran Acts. He states that the witness, who invoked the fifth amendment of our Constitution in refusing to answer questions concerning the Communist origin of the NCRMA, was the Communist Party's top commissar in the field of immigration. This does not mean, of course, that all who criticize the McCarran-Walter Act are Communists, or even Communist sympathizers, but it should cause patriotic Americans who have no political axe to grind to ponder before they join any movement to attack the law.

\section{Use of Unfilled Quotas}

Some foreign countries, notably those with large quotas, are not filling their annual allotments. On the other hand, some of the smaller quotas of other countries are not only filled annually, but are oversubscribed for many years to come by thousands of prospective immigrants registered on quota waiting lists at American consular offices abroad. These prospective immigrants and their agents, advocates, or sympathizers in the United States look covetously upon the unfilled portions of the quotas of other countries and contend that the national-origins quota system has failed, has not accomplished its purpose, and is out of balance because we are not actually receiving immigrants annually in the precise proportions envisaged under it. What they really object to is the fact that the McCarran-Walter Act has not changed the provisions of the old laws requiring a strict compartmentalization of the quotas.

An immigration quota is not, of course, a guarantee that the United States will actually receive any specific number of immigrants in any year from any quota country. A quota is a ceiling-not a floor-on the annual volume of immigrants chargeable to a quota country. If the overflow of immigrants from oversubscribed quotas were permitted to utilize the unfilled portions of undersubscribed quotas, this would not bring the national-origins system into proportionate balance, but, on the contrary, would further unbalance it. However, the advocates of such use of the unused portions of quotas are probably not really interested in matters of balance anyway.

The fact is that the national-origins system has not failed. Congress did not attempt to freeze or stabilize the ethnic composition of our people at the ro20 census level. Such an attempt would have required permanent fixation not only of permissible immigration, but also of actual immigration each year, as well as a similar control over the emigration and the birth and mortality rates of each nationalorigins group-a ridiculous undertaking for anyone to attribute to the national legislature. If, indeed, it had been the intention of Congress even to guarantee that

14 The American Mercury, Oct. 1955, p. 51 . 
we would actually receive annual immigration in a certain proportionate volume, the largest quota would have been designated as the "key quota," and all other quotas would have been usable only concurrently and at the same proportionate rate of utilization as the "key quota."

Congress knew in 1924 , when the national-origins quota system was originally introduced, that some of the quotas might not be filled in some years. Congress knows today that some quotas are not annually filled. However, Congress has taken no step toward bringing the quotas into a proportionate balance so far as immigrants actually arriving are concerned. On the contrary, in abandoning the theoretical world quota of 150,000 annually, Congress removed the ceiling over the world's quotas, a step in the direction of a readjustment of our national origins or a revision of the quotas to conform to present proportions of our various foreign national-origins groups.

It is estimated that if the census of $195^{\circ}$ were substituted for that of 1920 , the German quota might be increased from 25,814 to more than 50,000 annually, while the quota for Great Britain and Northern Ireland might be increased to more than 100,000 annually. As these two quotas are not being filled today, it is not likely that their enlargement would increase the volume of immigration under them. Increases accruing to the smaller quotas, on the other hand, would probably largely be used. The result would, thus, be an increase in the volume of actually arriving immigrants but in greater disproportion to our various foreign national-origins groups than at present. In fact, the truth is that in filling their quotas every year, while some of the larger quotas are not filled, the smallerquota countries today are actually enjoying a greater proportionate volume of immigration than if all quotas were filled annually.

The use of the unfilled portions of quotas which some critics advocate would necessitate the creation of a "jackpot" into which the unfilled portions of all quotas would be deposited, to be withdrawn by immigrants chargeable to oversubscribed quotas. "Jackpot bills" have been introduced in Congress year after year, but substantial support has never been mustered for such a diversion of unused quota numbers. Even the proponents do not agree among themselves on a method of dividing the "jackpot." And the executive branch of the Government historically has taken the position that if Congress should desire to make use of the unfilled portions of quotas under a "jackpot" plan, a statutory method of dividing the "jackpot" should be enacted, as it would be an invidious task, indeed, for any administrative officer to attempt such distribution.

On the question of administrative feasibility, it should be noted that the extent to which any quota is unfilled cannot be determined until the end of the quota year, when it would obviously be too late to use the unfilled portion in that year. Consequently, if any of the unused portions of quotas are to be utilized, it would seem to be administratively necessary that this be done in a subsequent year or years. If, during such year or years, any portion of the accumulated "jackpot" were unused, 
this might be added to the currently unfilled portions of the quotas for use in a subsequent year or years, and the snow-balling process that would develop could create an administrative monstrosity that no rational executive officer would be willing to attempt to manage. The budgetary and personnel planning for such a program alone would require a crystal ball of omniscient prophetic vision to determine when and where the shifting and fluctuating demand for operating funds and personnel would be required from month to month, to say nothing of day to day.

These are some of the reasons why every Congress has frowned upon the unusedquota "jackpot bills" and has favored the enactment of special legislation from time to time, along the lines of the Displaced Persons Act of $\mathbf{1 9 4 8}$, as amended, ${ }^{16}$ and the Refugee Relief Act of $1953^{16}$

\section{Other Possible Quota Systems}

Some critics advocate the complete abandonment of the national-origins quota system and the institution of an entirely new system. As charges have been made that the small-quota countries are objects of discrimination, it seems obvious that if such charges are to be obviated, no country should be given a quota smaller than that of any other country-but no one seems to advocate such a system of numerically equal quotas for all countries of the world. Perhaps the critics desire only to discriminate against other countries, on the theory that the national-origins system discriminates against the wrong ones. In any event, they are stuck with their own label of discrimination and can only remove it by advocating a system of numerically equal quotas for all countries.

It would, of course, be possible to fix each country's quota in proportion to its population among all other foreign countries, and, thus, the countries with the larger populations would be allocated the larger quotas. Aside from a possible recurrence of the charges of discrimination heard today, however, such a system would mean that the United States had relinquished its control over the quotas and surrendered them to the shifting tides and vicissitudes of foreign populations. It would also mean that the United States had, at last, been inveigled into undertaking, unwisely, the Herculean task of draining off the excess populations of some foreign countries without having within its power any means of preventing a continuous state of overpopulation in those countries. While the United States may bear some share of responsibility for the dislocation of populations resulting from conditions growing out of World War II, in which we were involved, in no sense can it be held responsible for the overpopulation of foreign countries resulting from high birth rates; and no foreseeable Congress is likely to enact any laws predicated upon the assumption of such responsibility.

It would also be possible to apportion each country's quota in accordance with

${ }^{15} 62$ STAT. Ioog (1948), as amended, 50 App. U. S. C. $\$$ 195I-63 (1952).

${ }^{10} 67$ STAT. 400 (I953), 50 App. U. S. C. A. $\$$ I97I (1955 Supp.). 
the proportionate demand in that country to the world demand for the privilege of immigrating into the United States. Here again, however, the United States would be surrendering its control over the quotas in favor of foreign migratory pressures and perhaps a sky-rocketing demand, real or fictitious, in each foreign country. Even if we could develop means of verifying the demand in each country, the basic defects of such a system would remain.

Some critics also urge that we play the role of the Good Samaritan and use our immigration quotas to relieve the excess-population problems of foreign countries. Notwithstanding the fact that we are spending billions of dollars to provide aid and relief in such countries, they would have us bring the objects of our charity to this country. But what did the Good Samaritan do? According to the Biblical story, as told by Jesus to St. Luke, a man had gone from Jerusalem to Jericho, where he fell among thieves, who stripped him of his raiment, wounded him, and departed, leaving him half-dead on a roadside. A priest and a Levite saw him there, but they passed him by, on the other side of the road. Then came the Good Samaritan. But let St. Luke finish the story in his own words: ${ }^{17}$

But a certain Samaritan, as he journeyed, came where he was; and when he saw him, he had compassion on him,

And went to him, and bound up his wounds, pouring in oil and wine, and set him on his beast, and brought him to an inn, and took care of him.

And on the morrow when he departed, he took out two pence, and gave them to the host, and said unto him; and whatsover thou spendest more, when I come again, I will repay thee.

It should be noted that St. Luke does not say the Good Samaritan took the poor man home with him, but rather "brought him to an inn." With respect to the aid and relief rendered by the Good Samaritan, the taxpayers of the United States are matching it, dollar for dollar, in foreign aid today. Moreover, we have welcomed to this country 237,790 immigrants, quota and nonquota, in the year I955, and some countries did not use one-third of their quotas.

There are, of course, other possible quota systems that could be adopted by the United States. In fact, the national-origins system is not the first, but rather the third system adopted by Congress. Under the first, introduced in the Act of May I9, I92X, ${ }^{18}$ each country's quota was fixed at three per cent of the number of people born in that country and residing in the United States according to the census of Igro. The use of the census of rgro, however, excluded from consideration the great volume of immigration immediately prior to the outbreak of World War I. An average of more than one million immigrants annually came to the United States during the five-year period, Igro to I9I4, inclusive, the total for that short period being 5,174,70r. And the term "United States," as used in the I92x Act, included most of our territories and outlying possessions, while most of the new immigrants settled in the continental United States.

${ }^{17}$ The Gospel of St. Luke 10:33-35.

${ }^{18}$ Act of May 19, I92 I, c. 8, 42 Stat. 5. 
The second quota system introduced in section $\mathrm{Ix}(\mathrm{a})$ of the Act of $1924,{ }^{10}$ was designed for temporary use-only until the national-origins quotas could be computed-and was, therefore, operative only between 1924 and 1929 . Under it, the quota of each foreign country was fixed at two per cent of the number of people born in that country and residing in the continental United States under the census of $\mathrm{I} 8 \mathrm{go}$.

Congress had become dissatisfied with the idea of basing quotas upon the number of our residents born in a foreign country, however, as place of birth is not necessarily determinative of nationality or ethnic background. Greeks born in Turkey for example, were counted in computing the quota for Turkey, and not the quota of Greece. Similarly, a Lithuanian resident of the United States born in Germany helped swell the quota for Germany rather than that of his own mother country. Moreover, the use of the i 890 census excluded from consideration the 18,218,761 immigrants who arrived in the United States between that year and 1920 . In the early I920's, too, Congress was besieged, as it is to a much lesser degree today, with individuals and organizations representing various foreign national-origin groups, demanding changes in our immigration laws.

Careful study led Congress to the conclusion that, while it would not be possible to satisfy all groups, essential justice could be done among them by making foreign national-origins groups, as a whole, instead of merely the foreign-born among them, the basis of quota allocations. As the question of enacting this national-origins quota system was approaching a decision in Congress, an editorial was published in the New York Times, in which it was stated:20

In formulating a permanent policy two considerations are of prime importance. The first is that the country has the right to say who shall and who shall not come in. It is not for any foreign country to determine our immigration policy. The second is that the basis of restriction must be chosen with a view not to the interest of any group or groups in this country, whether racial or religious, but rather with a view to the country's best interests as a whole. The great test is assimilability. Will the newcomers fit into the American life readily? Is their culture sufficiently akin to our own to make it possible for them easily to take their place among us? There is no question of "superior" or "inferior" races, or of "Nordics," or of prejudice, or of racial egotism. Certain groups not only do not fuse easily, but consistently endeavor to keep alive their racial distinctions when they settle among us. They perpetuate the "hyphen" which is but another way of saying that they seek to create foreign blocs in our midst.

A policy must be formed without discriminating unfairly against any given groups, but at the same time with regard to the interests only of the whole and not of any special part.

In reaching the Solomonic solution of basing the quotas upon the national-not racial-origins of our people, Congress was undoubtedly cognizant of the fact that a combination of the larger national-origins groups naturally included a majority of our voters, an element no Congress is likely to ignore.

${ }^{20}$ Act of May 26, 1924, c. 190, $\$$ II(a), 43 STAT. 159.

${ }^{20}$ N. Y. Times, March I, 1924, p. 12, cols. 2-3. 
Report of the Truman Commission

On September 4, 1952, President Truman created, by an Executive Order, ${ }^{21}$ a Commission on Immigration and Naturalization, which purported to make, in less than four months, a study of our immigration, deportation, nationality, and naturalization laws and policies, filing its report on January $\mathrm{I}, \mathrm{I} 953 .{ }^{22}$ As the Commission consumed the first two months of its life in becoming organized and holding hearings of testimony of witnesses largely comprising persons who were opposed to our immigraion laws, and as most of the fourth (last) month was used in writing its report, it had scarcely more than the intervening third month left for devotion to its primary task, which was to make a study of the laws and policies developed during our entire history.

In uttter disregard of the current polls of public opinion, reflected in Congress by the recent enactment of the McCarran-Walter Act over the veto of President Truman, this Commission filed a report which, with some amplification, followed the pattern of his veto message. It recommended that the national-origins quota system, which had just won a notable victory over the same arguments advanced in Congress, be abolished in its entirety. However, the Commission was unable to devise a substitute system and contented itself with a recommendation that another commission, of permanent character, be created to supersede the Secretary of State and the Attorney General in the administration of our immigration laws and to make a triennial distribution of the authorized annual volume of quota immigration, which would be called a blanket quota. Such distribution, the Commission said, should be made without regard to national origin, race, creed, or color, but bearing in mind such factors as asylum, reunion of families, needs in the United States, general immigration, and "needs in the free world." ${ }^{23}$

While the precise meaning of some of the terms suggested is not clear, such as the distinction between race and color in an ethnological or anthropological sense, and whether needs in the United States would be embraced within the term "needs in the free world" or whether the United States was not regarded by the Commission as a part of the free world, the Commission apparently believed that such ambiguities could be resolved by the proposed new commission. The Commission, however, succeeded in arousing less public sentiment against the McCarran-Walter Act than against its own report. In an editorial reflecting public reaction, The Saturday Evening Post stated: ${ }^{24}$

The center objective of this assault is the "national-origins" quota system, which has been used for the past quarter century as the formula for determining the distribution of immigrants among the various countries of origin. The national-origins quota is supposed to be discriminatory, based on "racism" and a threat to peaceful relations with other

${ }^{21}$ Exce. Order No. 10392, 3 C. F. R. 100 (Supp. 1952).

23 President's Comm'n on Immigration and Naturalization, Whom We Shall Welcome (i953). (1953).

${ }^{23}$ Id. at $263-64$.

24 The Saturday Evening Post, Feb. 21, 1953, p. 10, cols. r-2. 
countries. In place of this system, which bases quotas on the numbers of each nationality already in this country, the critics, as represented by Truman's last-minute Commission on Immigration and Naturalization, favor a blanket quota. The Commission then tries to figure out how to divide up the blanket quota among all the people who want to get in, without offending anybody. It cites "right of asylum" and "unity of families" and "relief of over-population" as guides to policy. A "board" would decide who gets in and who doesn't.

It is easy to see what would happen. The racial group with the best public-relations setup and the tightest squeeze on politicians would win all the arguments. The next thing you knew, the countries which had been discriminated against by all this "nondiscrimination" would be filing diplomatic protests, and a matter which has long been handled easily and automatically by the national-origins standard would be an issue in every election from Perk's Corners to the U.S.A. as a whole. As the BaLtmmoni Sun [January 3, 1953, p. 8] aptly remarked in discussing the proposal, "It would be like assigning the location of gasoline stations to the City Council."

But aside from the impracticability of the proposed substitutes for it, the nationalorigins system seems to us to represent pretty well the views of the average American on how new arrivals should be distributed among the various emigrating nations. Some people would like to see more Swedes and fewer Scotsmen admitted, but there is no universal demand for upsetting the present proportion of ethnic groups in our population. There is no demand to throw away a workable slide rule like the national-origins system in favor of a series of dog fights.

Nor is there any sentiment in favor of accepting the idea of the Truman Commission that immigration to this country should be determined less by the needs and capacities of this country than by the desires of other people to come here. For example, we cannot substantially relieve over-population by admitting 150,000 people a year to the United States. Much as we might wish to do so for humanitarian reasons, we cannot destroy our immigration standards to take care of people who are a surplus elsewhere. Americans are usually eager to accept displaced persons in emergency situations, but that does not mean that we can permit our permanent immigration policy to be decided primarily by tragedies and misfortunes elsewhere. To accept such a theory would be to Balkanize ourselves without materially benefiting anybody else.

It seems fairly certain that unless every foreign country's quota is computed upon the basis of a public, definite, and identical mathematical formula, so that all countries may know in advance what their quotas, as well as the quotas of other countries, will be from year to year, the Government of the United States may be deluged with both foreign and domestic complaints and charges of graft, corruption, undue influence, national bias or prejudice, special favoritism, and perhaps even national animosity. The flood of diplomatic protests alone could seriously interfere with the normal conduct of our foreign relations. Moreover, the internal strife which could be created by some justifiably dissatisfied foreign national-origins groups in the United States could well disrupt our national unity, and, thus, one of the prime objectives of the Kremlin for many years would, at last, be accomplished.

\section{Subquotas for Colonies}

The McCarran-Walter Act established a limitation upon the use by colonial possessions of the quotas of their governing countries. No colony may now use 
more than Ioo quota numbers annually from the quota of its governing country. ${ }^{25}$ Under the old law, there was no limitation, for example, upon the use of the British quota of $65,36 \mathrm{r}$ annually by eligible immigrants from the British colonial possessions, which include the Bahamas, Barbados, British Guiana, British Honduras, Cyprus, Hong Kong, Jamaica, the Leeward Islands, Malta, Trinidad, and the Windward Islands, each of which now has a subquota of roo annually. The self-governing countries of the British Commonwealth of Nations, such as Australia, India, New Zealand, and the Union of South Africa, and such independent countries as Egypt, Iran, Iraq, Israel, and the Philippines were already limited by the-old law to minimum quotas of roo annually. Under the McCarran-Walter Act, no colonial possession has access to a larger quota than that of any independent country of the world. The mere statement of this fact indicates the inherent equities in it; although it has been subjected to considerable attack.

Critics contend that the establishment of subquotas constituted an act of racial discrimination against the people of the British Crown Colony of Jamaica, which no longer has unlimited access to the annual British quota of $65,36 \mathrm{r}$. However, a similar charge has not been made with respect to the other British colonies, such as Cyprus and Malta, to which the subquota system also applies. Furthermore, the facts are that the British national-origins group among our people reflected in the national-origins mirror in I 920 was not substantially of British colonial origin, but rather consisted largely of people who originated in the British Isles. The subquotas now available to the British colonies total I, I00 annually and are not inequitable when viewed in the proper light of the proportionate reflection of British colonials in our national-origins mirror. The fact is that Congress has dealt generously with the colonial possessions of all countries. If they had been allotted subquotas in true proportion to their actual reflection in the national-origins mirror, they would not have been entitled to a quota of even roo immigrants annually.

\section{Quotas for Asian Countries}

The McCarran-Walter Act established quotas for the peoples of all Asian countries and, for the first time in our history, authorized quota immigration and naturalization in the United States for all aliens of Asian birth or Asian ancestry. ${ }^{26}$ The act abolished the Asiatic barred zone specified in the Act of February 5, I9r $7,{ }^{27}$ which barred from immigration into the United States the indigenous natives thereof, with few exceptions. The act created a new Asia-Pacific triangle of eligibility for quota immigrants born therein or belonging to races indigenous thereto. ${ }^{28}$ The Asia-Pacific triangle itself was allotted a quota of 100 annually, ${ }^{29}$ which is now available to quota immigrants of Asian ancestry not properly chargeable to the

\footnotetext{
${ }^{25} 66$ STAT. I76, 8 U. S. C. \$ II52 (1952).

${ }^{20} 66$ STAT. I75, 8 U. S. C. $\$ 115$ I (1952).

${ }^{27}$ Act of Feb. 5, 1917, c. $29, \$ 3,39$ STAT. 876 .

${ }^{28} 66$ STAT. I76, 8 U. S. C. $\$ 1152$ (1952).

20 Ibid.
} 
quota of any of the twenty-one countries within the triangle, each of which has a quota of at least roo.

Under the national-origins system, the countries of Asia were in a position similar to that of many colonies of European countries with respect to the computation of their quotas. If they had been allocated quotas in true proportion to their reflection in our national-origins mirror, some of them might not have been entitled to a quota of even one full number annually and, thus, could have sent us only one immigrant at intervals of several years. However, Congress was again generous in dealing with Asians under the McCarran-Walter Act by taking into consideration the fact that most of the peoples of Asia had been denied the privileges of quota immigration and naturalization in the United States throughout our previous history and, consequently, could not be expected to make a large reflection in our national-origins mirror. They were, therefore, exempted from the necessity of making any reflection at all.

As a counterbalance to a possibly disproportionate volume of Asian immigration, however, Congress provided that quota immigrants attributable by birth or ancestry to one or more countries in the triangle should generally be charged to the quota of a country within the triangle, or to the quota of the triangle. ${ }^{30}$ The act has been criticized, accordingly, because it did not grant to individuals of Asian ancestry the privilege of migrating under the quotas of European countries if they were born in such countries, or grant them nonquota status if they were natives of the independent countries of the western hemisphere. However, it was considered that if the thousands of people of Asian ancestry born in the quota countries of Europe were given access to such quotas, and if the 600,000 people of Asian ancestry born in the nonquota countries of the western hemisphere were granted the privilege of immigrating into the United States without numerical limitation, too drastic a change could result in the ethnic composition of the population of the United States, because the peoples of Asia would be deriving immigration privileges not only in great disproportion to their largest possible reflection in the national-origins mirror, but in even greater disproportion to the privileges granted any other of our foreign national-origins groups.

\section{III}

\section{Nonimmigrant Foreign Visitors}

There has been some criticism of the control of the admission of nonimmigrant foreign visitors to the United States under the McCarran-Walter Act. While it may be difficult to ascertain whether the criticism is attributable to some defect in the law, or to the manner in which it is administered, or to other causes, a consideration of the nature of the complaints and a brief history and analysis of the law should develop some indication as to where the fault lies.

From time to time, complaint is heard that some distinguished foreigner, world${ }^{30}$ Ibid. 
renowned in the arts or sciences, has been caught in the web of the McCarranWalter Act and either has been barred from coming to the United States or is experiencing difficulty in obtaining a visitor's permit. Due recognition must, however, be given to the fact that some of these complaints have been unwarranted with respect to either the law or the manner in which it was administered. Some people, unfortunately, have a tendency to exaggerate their own importance, especially as international travellers, and may artificially enlarge the alleged embarrassment suffered at the hands of an overworked travel-control officer, whose courtesy and demeanor may perhaps have left something to be desired even if there were provocations by a weary and irritable traveller.

There is also extant a school of thought which seems to hold that we are living in one small world, where international boundaries are not real, but are intangible figments of an outmoded capitalistic imagination; that our immigration laws and travel regulations are imaginary or fictitious barriers erected by the bourgeoisie to harass the proletariat.

And last, but by no means the least dissatisfied, is the critic who begs the question by asking why all the travel controls are necessary when most of the people travelling on the same vessel or plane with him are really very nice persons on legitimate business or pleasure. He, of course, is unaware of the numbers of wouldbe travellers who have been restrained because they are international crooks, confidence men, gangsters, illicit traffickers in narcotics, white-slave traffickers, persons with a dangerous contagious disease, potential assassins of public officials, espionage agents, or saboteurs. Outnumbering all of these classes, so far as the United States is concerned, are those who are unable to obtain immigrant visas because of qualitative or quantitative restrictions and who seek to enter the United States in the guise of nonimmigrant foreign visitors.

No informed person has advocated that aliens be exempted from our immigration laws merely because some person or organization has invited them to come to the United States, or because of their exceptional attainments in the fields of art or science, or because it is possible to travel faster today than in the past. The essence of the complaints seems to be that some means should be developed for expediting the admission of bona fide nonimmigrant foreign visitors. If the McCarran-Walter Act is an insurmountable obstacle to this end, it should, of course, be suitably amended; but if the basis for the complaints lies elsewhere it should constitute no adverse reflection on the existing law.

Prior to the enactment of the McCarran-Walter Act, the laws governing the travel of nonimmigrant foreign visitors to the United States were in a deplorably chaotic state. American consular officers were without authority to refuse nonimmigrant passport visas to aliens whom they knew to be subject to exclusion under our immigration laws upon arrival at a port of entry in the United States. Transportation lines were subjected to heavy fines and other penalties for bringing such aliens to our ports of entry, even when the aliens were in possession of valid nonimmigrant 
passport visas issued by an American consular officer abroad. This unusual state of the law stemmed from the fact that qualitative restrictions had been enacted long before documentary and procedural requirements were imposed, and the two phases of our statutory immigration laws had never been brought into practical coalescence.

The Act of February 5, I9I7 contained a long list of excludable classes of aliens, but no distinction was drawn between immigrants and nonimmigrants. Section 3 of the act did, however, contain a number of provisos, the ninth of which permitted the Attorney General to authorize the temporary admission of an otherwise excludable alien. ${ }^{31}$

Passport visas were first required of all aliens by a Joint Order issued by the Secretary of State and the Secretary of Labor on July 26, I917.22 However, the authority of American consular officers to withhold passport visas was limited to considerations of public safety, which constituted the basis for the Joint Order, and did not extend to all of the classes of aliens excludable under the I9I7 Act, the theory apparently being that such aliens should be permitted to proceed to a port of entry where they would be subject to detention until the Attorney General could determine whether he would authorize their temporary admission under the ninth proviso. The Act of May 22, $1918^{33}$ and the President's Proclamation ${ }^{34}$ and Executive Order ${ }^{35}$ issued pursuant thereto, in essence, merely confirmed and gave statutory authority for the issuance of the Joint Order; and the Act of March 2, $192 \mathrm{I}^{36} \mathrm{ex}-$ tended the authority into peace time, without substantive change.

Section 30 of the Alien Registration Act of $1940^{37}$ constituted the first direct statutory requirement of visas for nonimmigrants, but conferred no new authority to refuse such visas, except in the case of an alien who refused to be fingerprinted. The Act of June 20, $194 \mathrm{I}^{38}$ prohibited American consular officers from issuing a visa of any kind to an alien whose admission would endanger the public safety, but this was only a statutory confirmation of the authority originally conferred upon American consular officers by the Joint Order of 19I7. The Act of June 21, 194I authorized the President to prohibit the issuance of permits to enter-visas of all kinds-to aliens whose admission would be prejudicial to the interests of the United States, ${ }^{30}$ but this was not considered sufficient authority for American consular officers to refuse passport visas to all classes of aliens who would be subject to exclusion under the I917 Act upon arrival at a port of entry.

Up to the date of the enactment of the McCarran-Walter Act, then, American consular officers were required to issue passport visas to bona fide nonimmigrant

${ }^{31}$ Act of Feb. 5, 1917, c. 29, 39 STAT. 875.

32 U. S. Dep't of Justice, Immigration and Nattonality Laws 1042-45 (r953).

${ }^{33}$ Act of May 22, 19:8, c. 8I, 40 STAT. 559.

34 Proclamation No. 1473, Aug. 8, rgr8, U. S. Dep'T of Justice, op. cit. stipra note 32, at 1046-49.

${ }^{35}$ Exec. Order No. 2932, Aug. 8, 1918 , id. at $1050-63$.

${ }^{36}$ Act of Mar. 2, I92I, C. II3, 4I STAT. I205, I2I7 (1921).

${ }^{37} 54$ STAT. 673 (I940), 8 U. S. C. $\$ 45$ r (I952).

${ }^{38} 55$ STAT. 252 (I94I), 22 U. S. C. $\$ 228$ (I952).

3055 STAT. 252 (I94I), 22 U. S. C. $\$ 223-26$ (1952). 
aliens and permit them to proceed to our ports of entry where the Attorney General could determine whether to admit them under the ninth proviso.

The transportation lines contended before Congress, when the McCarran-Walter Act was under consideration, that they should not be subjected to heavy fines and other penalties, such as detention expenses and refund of passage money, for bringing excludable aliens to our ports of entry when such aliens were in possession of valid nonimmigrant visas issued by an American consular officer. Nor were the immigration authorities at our ports of entry satisfied with the state of the law, under which they were repeatedly placed in the difficult or embarrassing position of having to exclude an alien with a valid nonimmigrant visa or to prevail upon the Attorney General to exercise his discretionary authority and authorize them to admit the alien temporarily under the ninth proviso, which was usually accompanied by the requirement of a bond to be posted by the alien to guarantee his departure from the United States upon the expiration of the period for which he might be admitted.

Consider, too, the plight of the aliens who were issued nonimmigrant passport visas by American consular officers abroad, who were required to warn the aliens of the possibility of their exclusion at a port of entry; the long and often expensive journey made by the aliens to a port of entry in the United States; the long periods of detention at such ports until a determination could be made as to whether they should be admitted or excluded; and the long journey back home after having been excluded and deported from the United States.

The history of the period from I9I7 to the effective date of the McCarran-Walter Act of December 24, I952 is replete with the cases of aliens who arrived at our ports of entry with valid consular visas and were detained until an order of exclusion and deportation could be entered against them. A vast immigration detention station was maintained at Ellis Island in the harbor of New York, as well as at other ports of entry. Since the enactment of the McCarran-Walter Act, however, the Immigration and Naturalization Service has disposed of Ellis Island. Seldom do we hear of nonimmigrant foreign visitors being detained at our ports of entry. Such detentions, when necessary, now occur in foreign countries, where the ineligible aliens make their application to our consular officers for visas. Under the McCarranWalter Act, the transportation lines and the aliens themselves are able to place greater reliance upon the validity of a nonimmigrant passport visa issued by an American consular officer, because such officers now have the necessary authority to withhold the issuance of such visas from inadmissible aliens, either as immigrants or as nonimmigrants. It is possible, of course, for an American consular officer to err in the issuance of a visa to an excludable alien, or events may transpire after a visa is issued which may render the alien excludable; but such possibilities reflect no deficiency in the law.

The McCarran-Walter Act also relaxed some of the excluding provisions of the earlier law with respect to nonimmigrant aliens. ${ }^{40}$ Consider the case of an illiterate

${ }^{10} 66$ STAT. 182,8 U. S. C. $\$$ II 82 (1952). 
alien, for example. He may be a bona fide nonimmigrant coming to the United States on a temporary visit with relatives or friends, or to attend a wedding, or a funeral. Although still excludable as an immigrant because of illiteracy, the McCarran-Walter Act abolished illiteracy as a ground for the exclusion of nonimmigrants. Other grounds for the exclusion of immigrants were also repealed by the McCarran-Walter Act with respect to bona fide nonimmigrants.

Under the McCarran-Walter Act, the Attorney General still retains authority to authorize the temporary admission of an excludable nonimmigrant, except in two classes of dangerous subversives. An excludable nonimmigrant alien, thus, may still be able to obtain a passport visa at an American consular office abroad after his case has been submitted to the Attorney General and the Attorney General has indicated that he will authorize the alien's temporary admission at a port of entry. ${ }^{41}$ In the cases of distinguished foreign visitors, it is, of course, to be regretted that they must be detained abroad until the Attorney General agrees to authorize their admission at a port of entry notwithstanding some ground which may exist for their exclusion. The alternative, however, of returning to the old practice of detaining them at our ports of entry upon their arrival after a long journey to the United States and subjecting the transportation lines to heavy fines and other penalties for bringing them to our ports hardly seems to be a desirable one.

Perhaps too much concern should not be aroused by the fact that an American consular officer may require a longer period of time to issue a nonimmigrant visa than is required by a foreign consular officer in the United States to issue a visa to an American citizen who desires to travel abroad. Comparatively little pre-visa screening of American citizens is performed by foreign consular officers in the United States, not only because their countries are anxious to obtain travel dollars, but principally because foreign governments, in various degrees, exercise over foreign visitors within their territories an internal police-state control such as we have never known, and certainly do not desire, in the United States. A longer period of time may be required, particularly for an excludable alien, to obtain a visa for the United States; but after he arrives in this country and is admitted for a temporary visit, he is practically as free as any citizen to travel from place to place and engage in normal activities in this country without being subjected to the onerous harassments of an internal police-state control.

No honest defender of the McCarran-Walter Act would be so bold as to assert that it is a perfect law. Far from it. However, it is undoubtedly a vast improvement over the old laws, and it was the only viable alternative to such laws at the time of its enactment. As time goes on, the operation of the law will be studied by the Joint Committee of the Senate and the House of Representatives on Immigration and Nationality Policy, which was established under the act for that purpose. ${ }^{42}$ As amendments are shown to be desirable or necessary, they will undoubtedly be

${ }^{11}$ Ibid.

1266 STAT. 274, 8 U. S. C. $\$$ I106 (I952). 
made by Congress. No one desires unduly to restrict, harass; or burden legitimate nonimmigrant foreign visitors, and yet, the United States, as one of the. last great bulwarks of freedom in the world, can ill afford to adopt a policy so lax with respect to nonimmigrants that our national security would be jeopardized and the institutions and qualities which have made our country so attractive to the peoples of all countries of the world, both as immigrants whom we welcome to a new life in a new world and as friendly foreign visitors whom we delight in entertaining, would no longer exist.

\section{IV}

\section{Review of Consular Decisions}

Some critics of the McCarran-Walter Act cite, as one of its shortcomings, the absence of provision for an administrative or a quasi-judicial review of the decisions of American consular officers abroad in connection with the applications made to them for visas. No statute of the United States has ever specifically provided for such a review. This does not mean however, that the decisions of our consular officers are not reviewed or that aliens may have their applications for visas rejected without recourse from the whim, caprice, or otherwise arbitrary action of an Amercan consular officer. The Secretary of State at Washintgon exercises supervisory and administrative jurisdiction over the Foreign Service of the United States in all of its functions, which embraces the duties and responsibilities of American consular officers in visa cases. This supervision or administration is complete, and its effectiveness is not limited by any formal rules of evidence and procedure. And no Secretary of State has been willing to tolerate any incompetency or inefficiency on the part of American consular officers in the performance of their duties in visa cases. While the Secretary of State may not substitute his opinion for the decision of the consular officer, he has never failed to bring about a reversal of the consular decision, when he is convinced that it was wrong, by pointing out to the consular officer the error of fact, law, or procedure involved. If a responsible consular officer should arbitrarily refuse to change his decision, the Secretary of State may, in exercising his supervisory authority and administrative jurisdiction over the Forreign Service of the United States, transfer the officer from his post to other work or have him removed entirely from the Service upon the basis of appropriate charges of inefficiency and incompetency. No appellate or review board could possibly exercise a more effective jurisdiction.

The establishment of a Board of Review of Consular Decisions, with a formal procedure for handling cases under specific statutory jurisdiction, would tend to relieve the Secretary of State and his subordinate officers in the Department of State at Washington of the heavy burden they have carried for many years in their informal review of consular decisions in visa cases. Their task, as well as that of the consular officers, would undoubtedly be much lighter if they could merely refer all complaints to such a Board. Moreover, the creation of such a Board would 
bring a financial windfall to the lawyers and other practitioners before it. The aliens concerned, however, would be in no better position than they are today. It could be much worse, unless the Secretary of State should proceed to review the unfavorable decisions in which the Board had erred, which authority he would be compelled to exercise, as he does today, if miscarriages of justice were to be avoided. Furthermore, while it may be possible for Congress to create an administrative or quasi-judicial tribunal in the United States to review the decisions of American consular officers on applications for visas made by aliens residing in foreign countries, and, therefore, outside the jurisdiction of our courts, without conferring upon our courts any jurisdiction to review the decisions of the board-thus preventing possibly hundreds of thousands of visa cases from coming before our courts and clogging their dockets for many years to come-there. is no certainty that the Supreme Court of the United States would long recognize the board as having the dignity and authority of a court of last resort.

Another consideration is this: As the admission of aliens into the United States involves a privilege and not an inherent or an abstract right, and as aliens applying for visas in foreign countries are outside the jurisdiction of the United States and may go unpunished for crimes committed in connection with such applications, it may be desirable to limit access to our administrative and judicial tribunals to those who are within our jurisdiction, leaving visa cases to the devices of international law or possible treaties granting Americans reciprocal access to foreign tribunals.

\section{V}

\section{Conclusion}

There are other complaints regarding the McCarran-Walter Act that are so obviously unjustified that no space has been devoted to them, as it was intended to deal only with the criticism which, prima facie, may seem to the uninformed to be meritorious. Perhaps there will always be two schools of extremist thought in the United States on the subject of immigration. However, between the extremely retrictionist view, which would bar all aliens, and the opposite, but equally extreme, antirestrictionist philosophy, which would abolish all restrictions, there must be a large middle ground upon which unprejudiced and patriotic citizens may stand. In keeping our doors ajar to worthy aliens and preventing the unworthy from approaching them, we are not only holding aloft the beacon light of liberty and refuge for the unjustly oppressed, but, by the God-given right of our fathers who came here before us and built a nation with freedom and justice for all, we shall preserve it. 